\title{
PELATIHAN INDENTIFIKASI INDEKS SAHAM USA UNTUK MEMPREDIKSI FLUKTUASI IHSG: LINCOM ANALYSIS PADA NASABAH TYPE SWINGER RELIANCE SURAKARTA
}

\author{
Tri Widianto ${ }^{1)}$ Yenni Khristiana $^{2)}$ Nugroho Wisnu Murti ${ }^{3)}$ \\ Dosen Program studi S1 Akuntansi, STIE AUB SURAKARTA \\ Email; Triwidianto@stie-aub.ac.id, yenni.kristi@stie-aub.ac.id
}

\begin{abstract}
Capital market practices in the type of stock instruments undergo a shift in the way of analysis. This is not in line with the theory of stock fundamental analysis which explains that fundamental factors become the main variable in determining stock investment decisions for the long term. Fundamental analysis of stocks takes into account various factors including company performance, macroeconomic analysis and the industrial sector. The fundamental variable of stock analysis is used as a consideration of the investment portfolio of the stock for the long term. Users of these variables are usually the owners of capital with the type of investor. Investor type is the owner of capital with the main purpose of buying shares by expecting stock valuations in the long run and dividends, not short-term capital gains. The need for the development of applied science of technical analysis and fundamental analysis of stock investors who have a form of trading activities on a daily basis generally only conduct transactions on the capital market using speculation from each investor. This of course in terms of education that novice stock investors do must have the same time in obtaining maximum income in the trading stock market

This service is carried out on customers of PT Reliance Surakarta. There were 13 training participants, namely customers who became stock investors but did not trade every day for a short period of time. The service was held for 1 day. Expected outputs from the event are expected that after attending the training the participants are expected to be able to carry out fundamental and technical analysis of JCI fluctuations on a daily basis
\end{abstract}

Keywords: Stock index, JCI Fluctuation Prediction, Swinger Type

\begin{abstract}
ABSTRAK
Praktek pasar modal pada jenis instrumen saham mengalami pergeseran cara analisis. Hal ini tidak sejalan dengan teori analisis fundamental saham yang menjelaskan bahwa faktor fundamental menjadi variabel utama dalam menentukan keputusan investasi saham untuk jangka panjang. Analisis fundamental terhadap saham memperhitungkan berbagai factor antara lain kinerja perusahaan, analisis ekonomi makro dan sektor Industri. Variabel fundamental analisis saham ini digunakan sebagai pertimbangan portofolio investasi saham untuk jangka panjang. Pengguna variabel - variabel ini biasa adalah pemilik modal dengan tipe investor. Tipe Investor adalah pemilik modal dengan tujuan utama pembelian saham dengan mengharapkan valuasi saham pada jangka panjang dan deviden, bukan capital gain jangka pendek. Perlunya pengembangan ilmu terapan analisa teknikal dan analisa fundamental terhadap para investor saham yang memiliki bentuk kegiatan trading secara harian umumnya hanya melakukan transaski pada pasar modal dengan menggunakan spekulasi dari masing - masing investor. Hal ini tentu saja dalam hal edukasi yang investor saham pemula lakukan harus memiliki waktu yang ama dalam memperoleh penghasilan yang maksimal dalam bursa saham trading.

Pengabdian ini dilaksanakan terhadap nasabah PT Reliance Surakarta. Peserta pelatihan sejumlah 13 orang yaitu nasabah yang menjadi investor saham tetapi tidak melakukan trading setiap harinya dalam jangka waktu pendek.. Pelaksanaan pengabdian ini selama 1 hari. Luaran yang diharapkan dari pengadian
\end{abstract}


Vol.4, No.1 April (2020) ; p.33-37 ; https://e-journal.stie-aub.ac.id/index.php/wasana_nyata

ini diharapkan setelah mengikuti pelatihan peserta diharapkan mampu melakukan analisa fundamental dan teknikal terhadap fluktuasi IHSG secara harian.

Kata kunci : Indeks saham, Prediksi Fluktuasi IHSG, Type Swinger 


\section{PENDAHULUAN}

Praktek pasar modal pada jenis instrumen saham mengalami pergeseran cara analisis. Pergeseran tersebut adalah penggunaan variabel fundamental makro ekonomi sebagai pertimbangan keputusan portofolio jangka pendek. Hal ini tidak sejalan dengan teori analisis fundamental saham yang menjelaskan bahwa faktor fundamental menjadi variabel utama dalam menentukan keputusan investasi saham untuk jangka panjang. Teori ini ditegaskan oleh (Desmond, 2011: 4) bahwa analisis fundamental terhadap saham memperhitungkan berbagai factor antara lain kinerja perusahaan, analisis ekonomi makro dan sektor Industri. Variabel fundamental analisis saham ini digunakan sebagai pertimbangan portofolio investasi saham untuk jangka panjang. Pengguna variabel - variabel ini biasa adalah pemilik modal dengan tipe investor. Tipe Investor adalah pemilik modal dengan tujuan utama pembelian saham dengan mengharapkan valuasi saham pada jangka panjang dan deviden, bukan capital gain jangka pendek investor saham yang memiliki bentuk kegiatan trading secara harian umumnya hanya melakukan transaski pada pasar modal dengan menggunakan spekulasi dari masing - masing investor. Hal ini tentu saja dalam hal edukasi yang investor saham pemula lakukan harus memiliki waktu yang ama dalam memperoleh penghasilan yang maksimal dalam bursa saham trading.

Fluktuasi indeks saham tertentu yang dianggap kuat, seringkali diprediksi menjadi salah satu factor yang mempengaruhi perubahan indeks saham tertentu. Beberapa indeks saham tersebut tergabung dalam World Major Index. Saat ini (2018) World Major Index terdiri dari 47 index saham dunia termasuk didalamnya Indeks Harga Saham Gabungan (IHSG) Indonesia. Diantara 47 World Major Index tersebut, indeks saham Amerika Serikat memiliki 5 indeks saham dan merupakan negara yang membukukan jenis indeks saham terbanyak dalam World Major Index antara lain Dowjones 30, S\&P 500, Nasdaq Composite, Small Cap 2000 dan CBOE Volatility. Akan tetapi, Amerika Serikat sesungguhnya memiliki 14 major index yang pergerakannya tidak selalu sama. Sehingga prediksi atas perubahan IHSG tidak cukup jika hanya mempertimbangkan salah satu indeks tersebut, misalkan hanya yang memiliki nilai terbesar (Dowjones 30). Bahkan indeks tersebut hanya terdiri dari 30 anggota emiten saja. Dengan mempertimbangkan permasalahan diatas perlu diadakan kegiatan pelatihan identifikasi indeks saham USA untuk memprediksi fluktuasi ihsg : lyncom analisis terhadap nasabah reliance Surakarta type swinger.

\section{METODE DAN APLIKASI}

\section{Pemecahan Masalah}

Pengabdian kepada masyarakat hasil dari oenelitian ini menunjukkan semua jenis indeks saham amerika serikat berpengaruh signifikan terhadap indeks harga saham gabungan (IHSG) di Indonesia. Diantara beberapa composite indeks di Amerika Serikat, Dow Jones Composite memiliki pengaruh terbesar diantara indeks composite lain terhadap IHSG. Akan tetapi investor perlu memperhatikan dua jenis indeks amerika serikat antara indeksNYSE Composite dengan Dow Jones Composite dan OTCM ADR dengan Dow Jones Composite. NYSE Composite dengan Dow Jones Composite memiliki beda signifikan dalam mempengaruhi pergerakan IHSG Indonesia. Perbedaan tersebut, memberikan konsekwensi bahwa prediksi pergerakan IHSG berdasarkan indeks composite terbesar di Amerika serikat (dow jones), disarankan tetap memperhatikan pergerakan saham NYSE Composite dan OTCM ADR, karena saham tersebut memiliki beda yang signifikan dalam mempengaruhi IHSG. 
Realisasi Pemecahan Masalah

Kami team Pengabdian Kepada Masyarakat mewujudkan melaksanakan workshop pelatihan dengan menyampaikan informasi hasil pengabdian hasil penelitian yang pernah kami lakukan terhadap identifikasi indeks harga saham USA untuk memprediksi terhadap saham IHSG khususnya kepada para investor yang melakukan pembelian saham tidak secara harian atau mingguan.

\section{Khalayak Sasaran}

Kalayak sasaran dalam sosialisasi PKM hasil pengabdian hasil penelitian team STIE AUB Surakarta ini adalah nasabah atau investor - investor yang telah terdaftar sebagai mitra Reliance dalam menjalankan jual beli pada pasar Modal. Pengabdian masyarakat ini di ikuti oleh 20 nasabah Reliance yang terbiasa bertransaksi pada pasar modal dengan ritme transaksi lebih dari 3 bulan sekali.

Metode Pelaksanaan Pengabdian

Kegiatan pelaksanaan pengabdian ini dalam bentuk sosialisasi dan pelatihan dalam menganalisa Indeks Saham USA Untuk Memprediksi Fluktuasi IHSG. Adapun pelaksanaan kegiatan PKM ini dilaksanakan pada hari Senin tanggal 25 Juli 2019 di kantor Reliance Surakarta yang dilaksanakan pukul 13.00 wib - selesai, dan diikuti oleh 13 Nasabah.

Metode yang digunakan dari kegiatan pelatihan dan pendampingan ini yaitu :

1. Metode ceramah dan penyampain materi oleh tim Pengabdian kepada Masyarakat (PKM) STIE-AUB Surakarta menyampaikan materi hasil pengabdian hasil penelitian tentang Indeks Saham USA Untuk Memprediksi Fluktuasi IHSG dengan metode Lincolm analisis

2. Pelatihan menganalisa Indeks saham USA yang di pergunakan untuku dapat memprediksi tingkat Indeks Harga Saham Gabungan dalam menentukan transkasi beli ataupun jual yang dilakukan oleh tim Pengabdian Masyarakat (PKM) STIE-AUB Surakarta dimulai dari memberikan pemahaman terhadap pentingnya analisa tektical pada IHSG.

3. Diskusi dan Tanya jawab tim Pengabdian Masyarakat (PKM) STIE-AUB Surakarta memberikan kesempatan kepada peserta pelatihan untuk bertanya mengenai hal-hal belum jelas mengenai materi yang disampaikan

Konsultasi berkelanjutan kepada tim Pengabdian Kepada Mayarakat (PKM) STIE-AUB Surakarta jika masih diperlukan.

\section{HASIL DAN PEMBAHASAN}

Hasil dari kegiatan pengabdian masyarakat ini yaitu mensosialisasikan hasil dari penelitian ang telah dilakukan terhadap nasabah PT. Reliance Surakarta pada investor type swinger. Untuk menganalisa Index harga saham sectoral IHSG dengan mengacu pada analisis lyncom. pada tanggal 25 Juli 2019 sebanyak 13 peserta. Adapun hasil dari pelatihan ini adalah para peserta pelatihan memperoleh bekal dan keilmuan tentang bagaimana seorang investor type jangka pendek type swinger tidak harus menggunakan Analisa fundamental secara keseluruhan berdasarkan Fluktuasi saham IHSG tetapi dapat menggunakan analisis data tektical yang dapat dilihat secara jangka pendek pada grafik jual beli penutupan harga saham pada periode hari sebelumnya.

Ringkasan data time series berupa data harian flukstuasi indeks saham obyek pengabdian hasil penelitian yaitu data yang dapat diobservasi berdasarkan sampel hasil penelitian memiliki jumlah yang 
berbeda. Selisih data observasi antara Indeks Indonesia dengan Amerika Serikat tersebut disebabkan oleh frekwensi aktifitas bursa saham yang berbeda antar negara tersebut. Perbedaan frekwensi aktivitas tersebut, dapat menunjukan bahwa hari libur yang bersifat nasional yang juga meliburkan aktivitas bursa saham Indonesia lebih banyak dibandingkan dengan Amerika Serikat.

\section{KESIMPULAN DAN SARAN}

Dengan adanya pelatihan analisa Indeks harga saham USA terhadap transaksi IHSG diharapkan para investor mampu menunjukkan semua jenis indeks saham amerika serikat berpengaruh signifikan terhadap indeks harga saham gabungan (IHSG) di Indonesia. Diantara beberapa composite indeks di Amerika Serikat, Dow Jones Composite memiliki pengaruh terbesar diantara indeks composite lain terhadap IHSG. Akan tetapi investor perlu memperhatikan dua jenis indeks amerika serikat antara indeks NYSE Composite dengan Dow Jones Composite dan OTCM ADR dengan Dow Jones Composite. NYSE Composite dengan Dow Jones Composite memiliki beda signifikan dalam mempengaruhi pergerakan IHSG Indonesia. Perbedaan tersebut, memberikan konsekwensi bahwa prediksi pergerakan IHSG berdasarkan indeks composite terbesar di Amerika serikat (dow jones), disarankan tetap memperhatikan pergerakan saham NYSE Composite dan OTCM ADR, karena saham tersebut memiliki beda yang signifikan dalam mempengaruhi IHSG. Saran yang dapat disampaikan kepada pengabdian hasil penelitian selanjutnya adalah melakukan analisis berdasarkan beberapa indeks lain di dunia.

Dengan diadakan pelatihan ini semoga dapat merubah pemikiran terhadap para investor khususnya nasabah Reliance untuk menentukan transaksi pada Indeks Harga Saham Gabungan di Indonesia khususnya nasabah yang terbiasa dengan transaksi diatas 3 bulan -6 bulan sekali menjadi harian atau mingguan.

\section{DAFTAR PUSTAKA}

Bali, T. G., Brown, S. J. and Caglayan, M. O. (2014) 'Macroeconomic risk and hedge fund returns', Journal of Financial Economics. Elsevier, 114(1), pp. 1-19. doi: 10.1016/j.jfineco.2014.06.008.

Baridwan, Z. (1999) Intermediate Accounting. Yogyakarta, Indonesia: BPFE.

Desmond, W. (2011) Analisis Fundamental Saham. 2nd edn. Jakarta: Exceed.

Jogiyanto (2003) Teori Portofolio dan Analisis Investasi. 3rd edn. Yogyakarta, Indonesia: BPFE Yogyakarta.

Kewal, S. S. (2012) 'Pengaruh Inflasi, Suku Bunga, Kurs, dan Pertumbuhan PDB Terhadap Indeks Harga Saham Gabungan', Jurnal Economia, 8(1), pp. 53-64.

Murti, N. W. and Widyastuti, I. (2017) 'Merumusakan Pertimbangan Keputusan Cut Gain dan Cut Loss Aktifitas Jual Beli Saham Bagi Tipe Swinger dan Scalper', in Prosiding Seminar Nasional \& Call for Paper: Hasil Pengabdian hasil penelitian dan pengabdian kepada masyarakat Universitas Muhammadiyah Semarang, pp. 380-198.

Prasetiono, D. W. (2010) 'Analisis Pengaruh Faktor Fundamental Ekonomi Makro Dan Harga Minyak Terhadap Saham LQ45 Dalam Jangka Pendek Dan Jangka Panjang', Journal of Indonesia Applied 
Vol.4, No.1 April (2020) ; p.33-37 ; https://e-journal.stie-aub.ac.id/index.php/wasana nyata




Economics,

Universitas

Brawijaya, $4(1)$, pp.

$11-25$

Available

at:

http://jiae.ub.ac.id/index.php/jiae/article/view/123/151.

Raharjo, S. (2010) 'Pengaruh inflasi, nilai kurs rupiah, dan tingkat suku bunga terhadap harga saham di bursa efek indonesia', Jurnal PROBANK STIE AUB Surakarta. Available at: e-journal.stie-aub.ac.id.

Thobarry, A. A. (2009) 'Analisis Pengaruh Nilai Tukar, Suku Bunga, Laju Inflasi Dan Pertumbuhan GDP Terhadap Indeks Harga Saham Sektor Properti (Kajian Empiris Pada Bursa Efek Indonesia Periode Pengamatan Tahun 2000-2008 )', Thesis Magister Manajemen UNDIP. Available at: http://eprints.undip.ac.id/19029/1/ACHMAD_ATH_THOBARRY.pdf.

Werastuti, I. G. A. P. D. D. N. S. (2013) 'Faktor Fundamental Ekonomi Makro Terhadap Harga Saham LQ45', Jurnal Keuangan dan Perbankan, 17(2), pp. 211-219. Available at: http://jurkubank.wordpess.com. 